\title{
Sustained impacts of a hiking trail on changing Windswept Feldmark vegetation in the Australian Alps
}

Running Head: Hiking trail continues to impact a rare plant community

*Mark Ballantyne ${ }^{1}$, Catherine M Pickering ${ }^{1}$, Keith L McDougall ${ }^{2}$ and Genevieve T Wright ${ }^{2}$

1. Environmental Futures Centre, School of Environment, Griffith University, Gold Coast, Queensland 4222, Australia

2. Office of Environment and Heritage, PO Box 773, Queanbeyan, NSW 2620, Australia

*Corresponding author email: m.ballantyne@griffith.edu.au, telephone: +61(0)755528140

\section{Summary Text for Table of Contents}

The impacts of recreational trail use can cause disturbance to rare alpine plant communities and may act alongside changes in local climate. We assessed how the continued use of a hiking trail has caused localised alteration of composition in a rare alpine plant community disfavouring tramplingsensitive species and interrupting shrub succession despite general increases in diversity and abundance elsewhere likely due to improving climate. This result shows that trails can cause sustained damage irrespective of environmental conditions. 


\begin{abstract}
Damage to vegetation from tourism and recreation includes the impacts of hiking trails which may favour trampling tolerant plants over those that are more sensitive to this type of disturbance. To assess how continued use of a hiking trail coupled with changes in local climate to affect a rare Australian alpine plant community, we compared plant composition at different distances from a trail in 2013 during wetter conditions with that 10 years prior during a drought in 2003. In both years, only a few trampling tolerant graminoids and cushion plants were found on the trail surface which runs along the ridgeline. Species richness and cover in both surveys generally increased with distance from the trail, but there were differences between the windward and leeward sides of the trail. This included increased abundance of some species but continued disruption of shrub succession on the leeward side of the trail. There was an overall increase in species richness between the two surveys, and changes in the abundance of many species independent of trampling effects; possibly reflecting the more favourable/wetter conditions for plant growth in 2013. These results suggest that changes in climatic conditions can affect community composition, but that this has not negated the impact of the hiking trail on this rare community. With average temperatures increasing, and snow cover declining in the Australian Alps, it is likely that there will be even more changes in the Windswept Feldmark, including the potential colonisation of these ridges by more competitive species such as graminoids at the expense of the dominant shrub and some herbs that are already adversely affected by trampling. Longer-term monitoring of this rare community is imperative to better-understand community processes in relation to the impacts of trail use and climate change. Management options to reduce these impacts are discussed.
\end{abstract}

\title{
Keywords
}

Trails, tourism impacts, threatened communities, Windswept Feldmark, shrubs, climate change

\section{Introduction}

Nature-based tourism and recreation have increased and diversified over the past 50 years (Buckley 2009; Monz et al. 2010; Newsome et al. 2013), and by 2008 accounted for around 20\% of all tourism (Buckley 2009). Despite many positive effects of this growth such as economic stimulation, education and benefits to human health, increasing visitation to natural areas has had a range of negative environmental impacts (Liddle 1997; Pickering and Hill 2007; Farrell and Marion 2001; Monz et al. 2010; Monz et al. 2013). Trails are one of the most common types of infrastructure provided for, and created by visitors in natural areas and trail-based activities such as hiking are among the most popular (Leung and Marion 1999; Hill and Pickering 2006; Wimpey and Marion 2011). In response, much of the research in recreation ecology has assessed the impacts of trails on vegetation and soils (Liddle 1997; Cole 2004; Monz et al. 2010; Burns et al., 2013; Queiroz et al., 2014) including in Australia (Sun and Liddle, 1993; Scott and Kirkpatrick, 1994; Phillips and Newsome, 2002; Whinam and Chilcott, 2003; Mende and Newsome, 2006; Pickering and Hill 2007; Hill and Pickering, 2009).

Environmental impacts of trails include reduced cover, height and biomass of plants (Sun and Liddle 1993; Scott and Kirkpatrick 1994; Hill and Pickering 2006; Pickering and Growcock 2009), altered community composition (Kutiel et al. 1999; Hill and Pickering 2006; Kerbiriou et al. 2008), changes in soil chemistry (Malmivaara-Lämsä et al. 2008), soil erosion (Dale and Weaver 1974; Farrell and 
Marion 2002; Olive and Marion 2009) and soil compaction (Liddle 1997; Kissling et al. 2009; Marzano and Dandy 2012). The severity of these impacts is primarily a function of the frequency, intensity, timing and type of use as well as the tolerance, disturbance history and abiotic conditions of the community with many impacts localised to the immediate trail area (Cole 2004; Pickering et al. 2010; Monz et al. 2013). Experimental trampling trials have been used to assess resistance (a species' ability to resist disturbance) and resilience (a species' ability to recover from disturbance) of vegetation to specific levels of use and the nature of their response (Cole 1985; Leung and Marion 2000; Hill and Pickering 2009; Pickering et al. 2010; Monz et al. 2013). Observational studies of the impacts of trails have been used to assess the tolerance (resistance and resilience combined) of vegetation and soils to repeated use over time both for individual species and communities (Liddle 1997; Bernhardt-Römermann et al. 2011). This research has found that some of the most sensitive plants to disturbance have sclerophyllous traits such as erect above-ground perennating buds and hardened organ structures (Liddle 1997; Bernhardt-Römermann et al. 2011) as well as low primary productivity and slow growth rates (Liddle 1975).

Sclerophyllous shrubs appear to be among the most sensitive plants to trampling as their traits often lead to slow recovery once trampled (Bayfield 1979; Liddle 1997; Cole and Spildie 1998; Whinam and Chilcott 2003; McDougall and Wright 2004; Pickering and Hill 2007; Bernhardt-Römermann et al. 2011). Communities dominated by these types of shrubs are mainly found in sub-tropical or Mediterranean climates such as California's chaparral, the Mediterranean garrigue or phrygana, South African fynbos and the Australian montane and coastal heaths (Specht and Moll 1983). As a result of increasing tourism and other human use in many of these regions and the low trampling tolerance of these shrubs, some of these communities have become extensively degraded (Soule et al. 1992; Rickard et al. 1994). Damage to shrubs in these communities is obviously of concern as they are often keystone species influencing competition, facilitation and community succession (Callaway 1995; Moro et al. 1997).

One of the rarest shrub-dominated communities in Australia is Windswept Feldmark which occupies just 28.5 ha of the highest ridges of the Australian Alps in Kosciuszko National Park (Costin et al. 2000; McDougall and Wright 2004; McDougall and Walsh 2007). It is of high conservation significance as it contains a number of rare and threatened plants including the entire Australian population of the grass Rytidosperma pumilum, and most of the populations of two herbs, Ranunculus acrophilus and Euphrasia collina ssp. Iapidosa endemic to the Australian Alps (Costin et al. 2000; McDougall and Walsh 2007). The community grows on bare rocky areas and consists predominantly of small tufted graminoids and herbs many of which are associated with larger patches of the low, slow-growing dominant shrub Epacris gunnii (Barrow 1968; Costin et al. 2000; McDougall and Wright 2004). Due to strong winds across the ridgeline, there is limited snow cover in winter to insulate plants from low temperatures and abrasion from ice particles (Barrow 1968). The winds prune the dominant shrubs resulting in a prostrate growth-form and a cyclical succession from the windward to the leeward side of the ridgeline (Barrow 1968). Similar community structures resulting from high winds also occur in other alpine plant communities including Epacris serpyllifolia feldmark in Tasmania (Lynch and Kirkpatrick 1995).

The Windswept Feldmark in the Australian Alps is threatened through trampling by hikers and climatic change. A hiking trail traverses roughly $2.5 \mathrm{~km}$ of the ridgeline inhabited by Windswept Feldmark (McDougall and Wright 2004; McDougall and Walsh 2007). It was originally a pack-horse 
trail but in the 1950s, when cattle grazing ceased in this part of the Park, it was incorporated into a network of formalised hiking trails (Edwards 1977; McDougall and Wright 2004). Despite being a formal park trail, sections traversing Windswept Feldmark have received limited management and maintenance, and remain largely unsurfaced and braided in places, with some users venturing offtrail to enjoy the mountain scenery (McDougall and Wright 2004). The alpine area is a popular destination for nature-based tourism and recreation with many associated impacts affecting a range of high conservation ecosystems and species (Pickering et al. 2003). As a whole, the alpine area is used by over 47,000 people a year with around 3,600 people hiking the more remote trail through the Windswept Feldmark (Pickering and Buckley 2003; Growcock 2006).

A vegetation survey in 2003 found that the trail had altered vegetation composition including the abundance and succession of the dominant shrub adjacent to the trail particularly on the lee side of the trail (McDougall and Wright 2004). The survey took place during a long drought associated with a long period of El Niño conditions in south-eastern Australia from 2003 to 2006 where average total annual alpine rainfall was just 1,125mm (Australian Government 2013). More recently, climatic conditions became wetter reflecting La Niña conditions, with annual rainfall averaging $1,350 \mathrm{~mm}$ in this alpine region (Australian Government 2013). These wetter conditions likely provided more favourable growing conditions to this otherwise wind-parched and exposed community. This provided an opportunity to see if the impacts of the trail changed when conditions were potentially more favourable for plant growth.

We resurveyed the same area of Windswept Feldmark in 2013 as surveyed in 2003, to determine if species diversity, frequency and composition: 1) changed between the two surveys, 2) differed in relation to distance from the trail and 3 ) might relate to either release from possible drought stress since 2003, continued use of the trail, or an interaction of both. We hypothesised that there would generally be increases in diversity in the feldmark primarily attributable to increased frequency of more competitive species that may be favoured by wetter conditions, but that vegetation on and close to the hiking trail would still be missing species more sensitive to trampling.

\section{Methods}

\subsection{Study Area}

Windswept Feldmark is a tundra-like plant community restricted to the north-south Main Range ridgeline of Kosciuszko National Park that links several of the highest mountains in Australia (Costin et al., 1979; McDougall and Wright, 2004). Strong westerly winds here restrict snow cover in winter resulting in plants being exposed to cold temperatures (average $3^{\circ} \mathrm{C}$ per annum) and abrasion from ice-particles throughout the year (Barrow 1968). Unlike nearly all other alpine plant communities in this part of the Australian Alps, Windswept Feldmark is characterised by limited vegetative cover, low plant diversity and shallow soils. Soils along the ridgeline are composed of thin alpine humus and metasediments covered by loose sedimentary shale. The dominant shrub E. gunnii is slowgrowing $(<1 \mathrm{~cm}$ per year), prostrate and sclerophyllous occurring as discrete, scattered plants around $100 \mathrm{~cm}$ in diameter and $10 \mathrm{~cm}$ in height, accounting for around $25-50 \%$ of total cover in the community (Costin et al., 2000; McDougall and Wright, 2004) (Figure 1). Due to the effects of the dominant westerly winds pruning vegetation, this shrub grows downwind from the windward westerly side of the ridgeline to the leeward eastern side (Barrow et al., 1968; McDougall and Wright, 2004). The tough canopy of small leaves of $E$. gunnii is thought to protect other lower- 
growing species from the extreme climatic conditions associated with the ridgelines, where they may otherwise be excluded (Costin et al., 2000; McDougall and Wright, 2004).

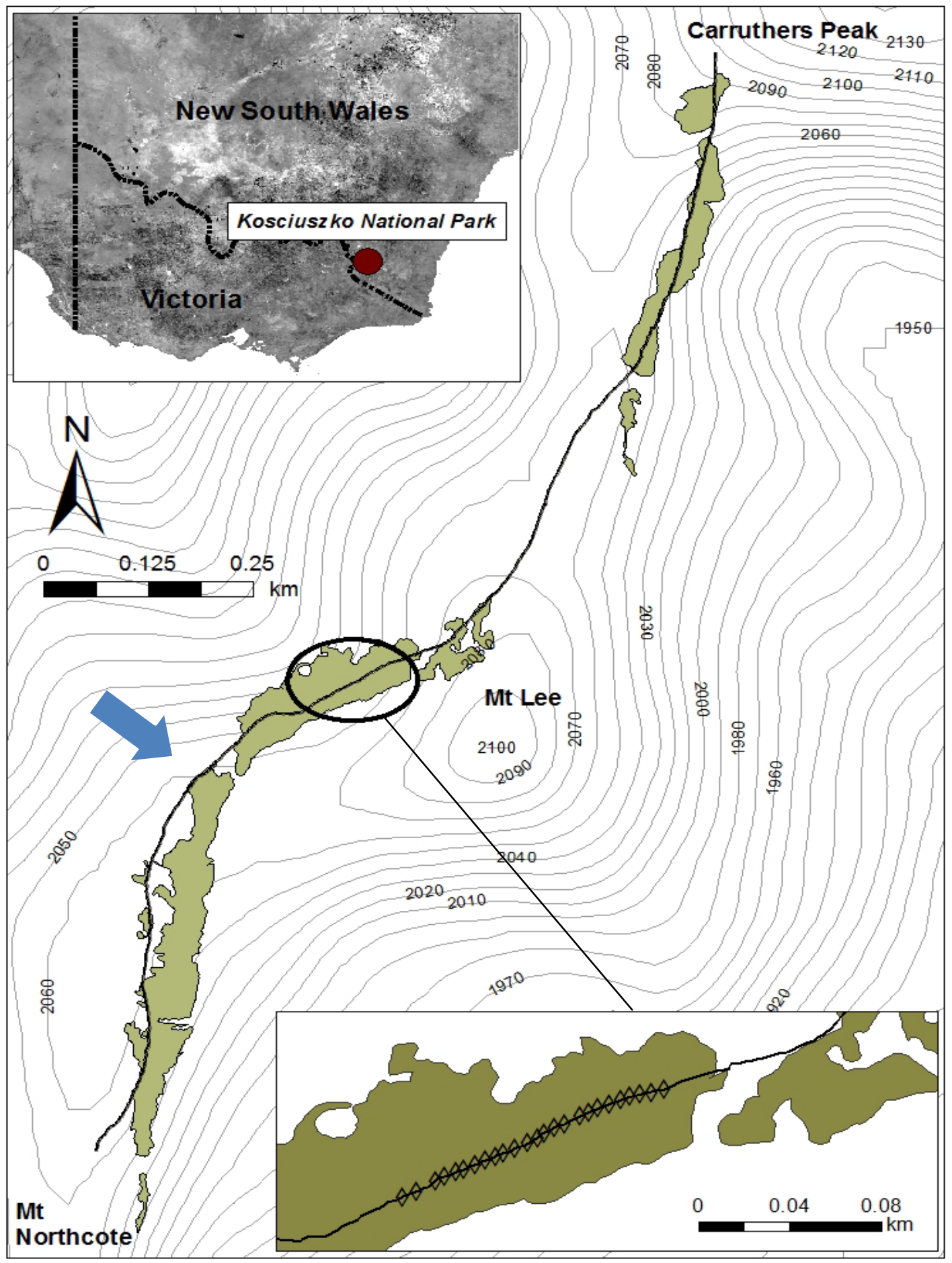

Figure 1: Location of the Windswept Feldmark patch surveyed (circled) between Carruthers Peak $\left(36^{\circ} 24^{\prime} 28.63^{\prime \prime} \mathrm{S}, 148^{\circ} 17^{\prime} 29.34^{\prime \prime} \mathrm{E}\right)$ and Mount Northcote ( $\left.36^{\circ} 25^{\prime} 50.44^{\prime \prime} \mathrm{S}, 148^{\circ} 16^{\prime} 50.84^{\prime \prime} \mathrm{E}\right)$. Map also shows the total 5.4ha area of Windswept Feldmark on the Main Range ridgeline with $2.5 \mathrm{~km}$ of hiking trail traversing it. The arrow signifies predominant wind direction. Inset map shows 25 trail transect points from 2013 survey (diamonds). Contour lines and inset satellite map of Australia from Geoscience Australia: Topo 250K Series 3 package and 1 second SRTM derived 3-second smoothed digital elevation model. Map created in ArcMap Version 10.1. 


\subsection{Sampling}

The 2003 and 2013 surveys were conducted in a 1.43 ha area of Windswept Feldmark at 2,060 m a.s.l. between Carruthers Peak to the north $\left(36^{\circ} 24^{\prime} 28.63^{\prime \prime} \mathrm{S}, 148^{\circ} 17^{\prime} 29.34^{\prime \prime} \mathrm{E}\right)$ and Mount Northcote to the south $\left(36^{\circ} 25^{\prime} 50.44^{\prime \prime}\right.$ S, $148^{\circ} 16^{\prime} 50.84^{\prime \prime}$ E) (Figure 1). To allow comparison with the results of the previous survey, the same protocols were used as in McDougall and Wright (2004) with vegetation surveyed in $1 \times 0.5 \mathrm{~m}$ quadrats (each divided into 32 sub-quadrats) located at fixed distances along 25 separate line-transects spread over a $150 \mathrm{~m}$ section of trail (Figure 1). The trail centre formed the midpoint of the transects which extended $10 \mathrm{~m}$ towards the windward (west) and $10 \mathrm{~m}$ to the leeward (east) sides of the trail. Seven quadrats were located per transect, with quadrats at $10 \mathrm{~m}$ and $5 \mathrm{~m}$ on the windward side of the trail, on the windward edge of the trail, on the centre of the trail, on the leeward edge of the trail and at $5 \mathrm{~m}$ and $10 \mathrm{~m}$ on the leeward side of the trail.

The 175 quadrats along seven transects used in 2003 were not permanently marked and so individual quadrats and transects could not be resurveyed in 2013. However, the same area of feldmark was surveyed using the same sampling methods in both years, with one of the people who conducted the first survey (Wright), involved in the second, including training and repeated validation of the methods and species identification for the other two people involved in the 2013 survey (Ballantyne and Pickering). Therefore a total of 350 quadrats were surveyed across the two surveys (175 in 2003 and 175 in 2013), and the experimental design was not a repeated measures ANOVA, but rather a Two-Way ANOVA design with distance from the transects (here in referred to as 'treatment') and year as the two independent variables (Underwood 2002).

Within each individual quadrat, the presence/absence of all vascular plant species was recorded and species richness per quadrat calculated, with taxonomy according to The New South Wales flora online (PlantNET, 2013). In addition the abundances of five key species were recorded in each quadrat as the total number of plants of Rytidosperma pumilum, Euphrasia collina ssp. lapidosa, Ranunculus acrophilus and Colobanthus pulvinatus and the total number of sub-quadrats containing Epacris gunnii. Density counts were not feasible for Epacris gunnii as plants are large and individuals are often indistinguishable.

\subsection{Data Analysis}

Data from quadrats for both years $(\mathrm{N}=350)$ were entered into Excel, IBM SPSS Statistics Version 21, $R$ Version i386 3.0.1 and Primer Version 6 for analysis. The frequency of each species across treatments and between years (2003 and 2013) was calculated. Differences in abundance (observed total number of quadrats) were compared across species and growth forms (shrub, herb, graminoid and cushion) between years using Chi-square goodness of fit tests in SPSS for all species and growth forms with presence $>10$ between the two years and minimum expected frequency $>5$.

To assess the tolerance of individual species to trampling, we compared the relative frequency among treatments for 17 species that occurred in 10 or more quadrats across all 350 quadrats surveyed (e.g. both years). Data from both years was combined in this analysis to increase the sample size for calculating frequencies. We calculated their relative frequency in trail and trail edge quadrats compared to quadrats $5 \mathrm{~m}$ and $10 \mathrm{~m}$ from the trail. Values were given as percentage using the formula 
$((\mathrm{Na} * \mathrm{P}) / \mathrm{Nb}) * 100$

where $\mathrm{Na}$ is the number of quadrats on the trail (heavy trampling) or on the trail edges (light trampling) in which the species was present, $\mathrm{P}$ is a multiplier to account for the higher number of quadrats (200) at $5 \mathrm{~m}$ and $10 \mathrm{~m}$ from the trail [such that trail quadrats (50) were multiplied by 4 , and trail edge quadrats (100) by 2] and $\mathrm{Nb}$ is the number of quadrats at $5 \mathrm{~m}$ and $10 \mathrm{~m}$ from the trail with that species. We also compared cumulative relative frequency among growth forms by combining the number of quadrats in which each species was present and then assigning those totals to growth form categories. Chi-square tests were used to compare values among treatments adjusted for differences in the number of quadrats in each treatment (Greenwood and Nikulin 1996).

For species richness and the abundance of the five key species, the effect of year and treatment were assessed using Two-Way ANOVAs in SPSS for all dependent variables that satisfied the assumption of normality and homogeneity of variance (species richness untransformed data, Colobanthus pulvinatus and Ranunculus acrophilus square-root transformed data and Epacris gunnii square-root transformed data excluding trail quadrats) (Underwood 2002). We used $95 \%$ confidence intervals (if there was a significant interaction) and Tukey HSD post-hoc tests (if no significant interaction) to compare treatments (Underwood 2002). As the quadrats were not permanently marked in 2003, year could not be analysed as a repeated measure.

Due to the large number of quadrats with no Rytidosperma pumilum or Euphrasia collina ssp. lapidosa, a zero-inflated Poisson and a zero-inflated negative-binomial model (Lambert 1992; Ridout et al. 2001; Zuur et al. 2009) were used to analyse their abundance in the statistical package $R$ ( $R$ Core Development Team 2013). These two-component mixture models partition the zeros as hailing from two separate processes; those from the point mass at zero, and those from the actual count data distribution (See Zeileis et al. 2008 and Zuur et al. 2009 for an outline of formulae and application using the R package). Tamhane's T2 post-hoc test was used on main effects where interactions were not significant, as this test does not assume equal variance.

Beta or community-level change in diversity was compared among years and treatments using ordinations on quadrat composition in the multivariate statistical package PRIMER (version 6) similarly to Bishop et al. (2010). A Bray-Curtis dissimilarity matrix was calculated on untransformed presence/absence data for all species in quadrats across the community sample. Non-metric multidimensional scaling (MDS) was used to graphically describe maximum variation among quadrats using two dimensions, recording the closeness of fit of these axes to the dissimilarity matrix as a stress value. This method visually represents patterns in community structure through the clustering and ordination of samples (Clarke 1993).

To test for significant differences in community composition between treatments and years, a Twoway Analysis of Similarity (ANOSIM) was calculated from the presence/absence dissimilarity matrix using 999 random permutations. This non-parametric permutation-based test is similar to the analysis of variance (ANOVA) but does not require a normalised distribution and uses multiple dependent variables (Clarke 1993). The SIMPER function was used to determine which species contributed most strongly to dissimilarities among years and treatments. Multi-dimensional scaling graphs were produced to graphically portray the clustering patterns using a Pearson correlation to show which species had the greatest effects. 


\section{Results}

\subsection{Changes in the Windswept Feldmark between 2003 and 2013}

There was a total of 27 species recorded in the community including 15 herbs, six graminoids, three shrubs, two cushion plants and one clubmoss (Appendix 1). The most frequently encountered species across the 350 quadrats overall were the graminoids Luzula australasica ssp. dura (336 quadrats; 96\%) and Trisetum spicatum ssp. australiense (309; 88\%), the cushion plant Colobanthus pulvinatus (318; 91\%) and the herbs Ranunculus acrophilus (289; 83\%) and Euphrasia collina ssp. lapidosa (277; 79\%) (Appendix 1). The dominant shrub Epacris gunnii occurred in 257 quadrats (73\%).

Total diversity significantly increased between 2003 and 2013 with 20 species recorded in 2003 and 26 species in 2013. Of the seven new species, two were relatively frequent including the grass Agrostis muelleriana (84\% of 2013 quadrats) and the shrub Epacris petrophila (15\%) while the other new species, mostly herbs, were much less frequent, being found either in a single quadrat or in less than 5\% (Appendix 1). Total species richness significantly increased in each of the five zones sampled, ranging from an increase of two species in the control zones to seven species in both lee zones (Table 1).

In addition to the entirely new species in 2013, there were increases in the frequency of the dominant shrub Epacris gunnii, several herbs (Ewartia nubigena, Leucochrysum albicans ssp. alpinum and Scleranthus singuliflorus), and the grass Poa fawcettiae. In contrast, there were two species that were recorded in fewer quadrats in 2013: the grass Trisetum spicatum ssp. australiense and the shrub Kelleria dieffenbachii (Appendix 1). As a result of the increase in the total number of species and the frequency of some species, species richness per quadrat also increased from $7.6 \pm 1.9$ to 8.8 \pm 2.1 between the two surveys (Figure 2a, Table 1). Overall there was no change in the cumulative number of quadrats with shrubs, herbs and cushion species between years, but there was a $29 \%$ increase in the frequency of graminoids (Table 2).

There were changes in the abundance of some key species between surveys. This included increased cover of the dominant shrub Epacris gunnii which went from $11 \pm 10$ sub-quadrats per quadrat in 2003 to $13 \pm 11$ in 2013 (Figure 2b, Table 1). In contrast, there was a 73\% decline in the number of plants per quadrat for the endemic herb Euphrasia collina ssp. lapidosa for all treatments except on the trail where it was very rare on both occasions (Figure 2c, Table 1). For the cushion plant Colobanthus pulvinatus (Figure $2 \mathrm{~d}$ ) and the very rare grass Rytidosperma pumilum (Figure 2e), there was a year effect, but also an interaction between year and treatments (Table 1). There was no change in the number of plants per quadrat for the endemic herb Ranunculus acrophilus between surveys (Figure $2 \mathrm{f}$, Table 1 ). 
Table 1: Statistical results for analyses on species richness and abundance of 5 key species for independent variables treatment, year and an interaction

Type of analysis in parentheses next to dependent variable. Bold values indicate significant results. $F$ value is a test statistic indicating the mean of within group variances, while $Z$ value provides an average number of standard deviations an observation is around the mean. The $p$ value is a probability value signifying the likelihood of obtaining a test statistics at least as extreme as observed given that the underlying null hypothesis is true, such that values $<0.05$ show significant differences in group means

\begin{tabular}{|c|c|c|c|}
\hline Dependent Variable & $\begin{array}{l}\text { Independent } \\
\text { Variables }\end{array}$ & Statistic & $p$ value \\
\hline \multirow[t]{3}{*}{ Species richness (2-way ANOVA) } & Time & $F=56.580$ & $<0.001$ \\
\hline & Treatment & $F=39.979$ & $<0.001$ \\
\hline & Interaction & $F=0.869$ & 0.518 \\
\hline \multicolumn{4}{|l|}{ Number of sub-quadrats } \\
\hline \multirow[t]{2}{*}{ E. gunnii (1-Way ANOVA) } & Time & $F=4.563$ & 0.033 \\
\hline & Treatment & $F=20.213$ & $<0.001$ \\
\hline \multicolumn{4}{|l|}{ Number of plants } \\
\hline \multirow[t]{3}{*}{ C. pulvinatus (2-Way ANOVA Square-root) } & Time & $F=28.971$ & $<0.001$ \\
\hline & Treatment & $F=16.038$ & $<0.001$ \\
\hline & Interaction & $F=3.172$ & 0.005 \\
\hline \multirow[t]{3}{*}{ R. acrophilus (2-Way ANOVA Square-root) } & Time & $F=0.035$ & 0.852 \\
\hline & Treatment & $F=12.541$ & $<0.001$ \\
\hline & Interaction & $F=0.930$ & 0.473 \\
\hline E. collina ssp. lapidosa (Zero-inflated negative & Time & $Z=-5.453$ & $<0.001$ \\
\hline \multirow[t]{2}{*}{ binomial regression) } & Treatment & $Z=3.662$ & $<0.001$ \\
\hline & Interaction & $Z=0.432$ & 0.665 \\
\hline R. pumilum (Zero-inflated negative & Time & $Z=-0.681$ & 0.495 \\
\hline \multirow[t]{2}{*}{ binomial regression) } & Treatment & $Z=3.622$ & $<0.001$ \\
\hline & Interaction & $Z=-2.245$ & 0.02 \\
\hline
\end{tabular}


Table 2: Cumulative frequencies of all species grouped by growth form between the two years (times)

Chi-square test results show goodness of fit for significant increases in frequency of growth forms since 2003 with significance indicated in bold

\begin{tabular}{|c|c|c|c|c|}
\hline \multirow[t]{2}{*}{ Growth Form } & \multicolumn{2}{|c|}{ Cumulative Frequency } & \multirow[t]{2}{*}{$\%$ Increase } & \multirow[t]{2}{*}{ Chi-square } \\
\hline & 2003 & 2013 & & \\
\hline Shrubs & 179 & 194 & 8.4 & 0.437 \\
\hline Herbs & 425 & 470 & 10.6 & 0.133 \\
\hline Graminoids & 516 & 668 & 29.4 & $<0.001$ \\
\hline Cushions & 194 & 200 & 3.1 & 0.762 \\
\hline
\end{tabular}

Changes in the presence and abundance of individual species contributed to significant changes in composition between 2003 and 2013, but the effect was dependent on the location of the quadrats in relation to the track with a significant year by treatment effect (Figure 3, Two-Way ANOSIM, Year Global Rho $=0.294, p<0.001$, Stress $=0.2$ ). The shifts in composition between years were most likely due to the increase in the total species pool, along with increases in the frequency of the grasses Agrostis muelleriana (14.5\% contribution to differences between years, SIMPER), Poa fawcettiae (8.8\%) and the dominant shrub Epacris gunnii (7.4\%). 

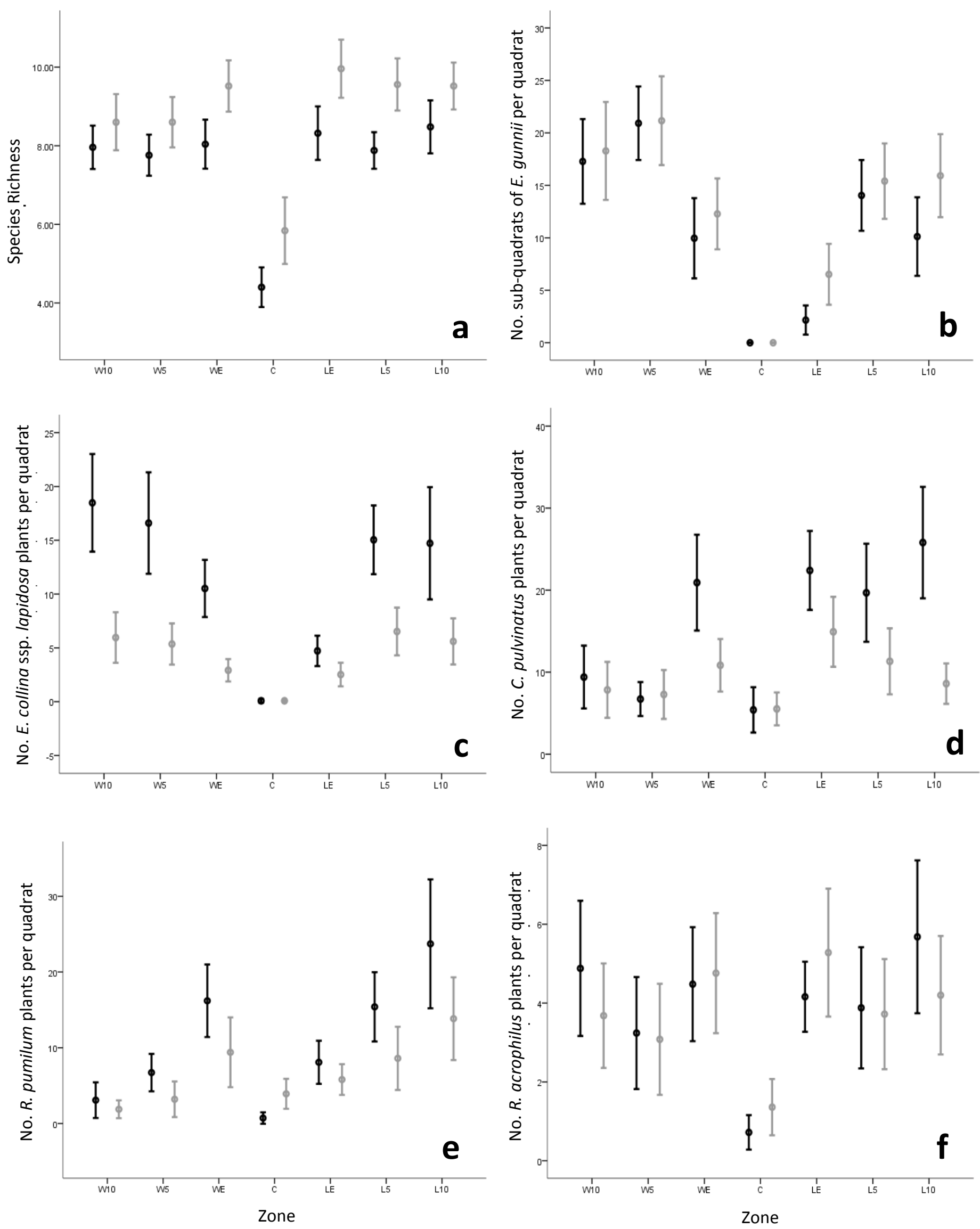

Figure 2: Mean and 95\% confidence intervals for: main effects of year and treatment on species richness (a), the number of sub-quadrats in which Epacris gunnii was present per quadrat (b) and the number of plants per quadrat of Euphrasia collina ssp. Iapidosa (c), Colobanthus pulvinatus (d), Rytidosperma pumilum (e) and Ranunculus acrophilus (f). Black lines represent data for the year 2003 and dark grey lines for 2013. 


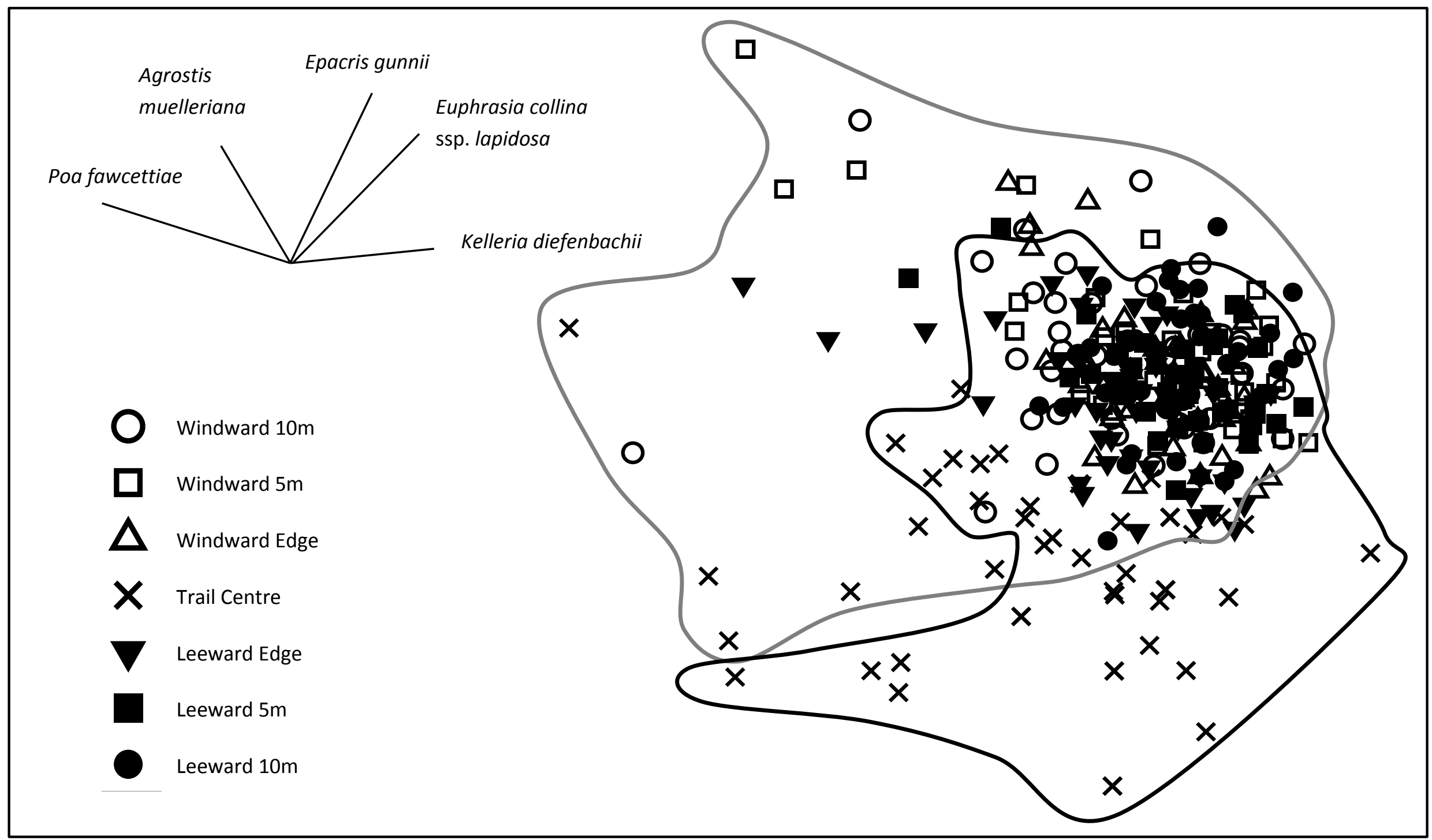

Figure 3: Multi-dimensional scaling (MDS) plot (based on Bray-Curtis similarity matrix) showing the clustering of quadrat points based on presence/absence composition data for all 7 treatments between the 2 years. Spearman correlation lines (top left) highlight species with the strongest contribution to the observed patterns of composition over time with length of line representing strength of influence. Black line encircles 2003 data and grey line shows 2013 data. Stress $=0.2$ and correlation coefficient set at $>0.5$. 


\subsection{Effects of the trail through the Windswept Feldmark}

Trampling had a range of impacts on the Windswept Feldmark in both years including on species richness, the number of quadrats with specific species and growth forms, the number of plants per quadrat for key species and overall community composition. For this section, both the trail edge quadrats and the $5 \mathrm{~m}$ and $10 \mathrm{~m}$ quadrats were grouped for ease of interpretation.

\subsubsection{The trail}

Few species grew on the trail surface, resulting in low species richness per trail quadrat (Figure 2a, Appendix 2). Relatively common species in Windswept Feldmark that were completely absent from the trail include the dominant shrub Epacris gunnii and the herbs Leucochrysum albicans ssp. alpinum, Scleranthus singuliflorus and Veronica densifolia (Table 3, Appendix 1). Some species occurred on the trail, but significantly less frequently than away from the trail including the small shrub Kelleria dieffenbachii and the herb Senecio pectinatus var. major (Table 3, Appendix 1). Overall, shrubs and herbs were particularly sensitive of trampling, occurring less frequently on the trail itself than its edges or further away $(-90 \%$ and $-70 \%$, respectively) (Table 3, Appendix 1$)$. Graminoids and cushion plants did not appear to be affected by trampling, occurring at similar frequencies across all treatments. Overall composition was, therefore, very different for trail quadrats compared to those on the edges and further away from the trail, with the graminoids Luzula australasica ssp. dura, Trisetum spicatum ssp. australiense and Poa fawcettiae and the cushion plant Colobanthus pulvinatus most characteristic of the limited vegetation on the trail itself (ANOSIM, $\mathrm{p}=<0.001$, and SIMPER analysis).

\subsubsection{Trail edges}

Although there were some differences in vegetation between the trail edges and further away, they were not as pronounced as between the trail itself and further away. Many species were found as frequently on the trail edges as further away (Appendix 1 ) and there were no significant differences in the number of plants on the trail edge compared to further away for some key species including Colobanthus pulvinatus, Ranunculus acrophilus and Rytidosperma pumilum (Figure 2, Table 1, Appendix 2). There was an edge effect for the endemic herb Euphrasia collina ssp. lapidosa and the dominant shrub Epacris gunnii, with significantly fewer plants or reduced cover on the leeward edge of the trail compared to the windward edge and further away (Figure 2, Appendix 2). Possibly as a result of the decreased cover of the dominant shrub on this edge, the two herbs Ranunculus acrophilus and Senecio pectinatus var. major were up to three times more abundant here compared to the windward edge and the windward side of the trail (Appendix 1). There were also some species that were frequent on both trail edges, more so than all other treatments, including the cushion plant Ewartia nubigena, the small shrub Kelleria dieffenbachii and the grass Rytidosperma pumilum. 
Table 3: Relative tolerance of plant species and growth forms to trampling based on presence/absence data for the two years (times) combined.

The trail centre values were derived from a total of 50 quadrats, the edges from 100 and the $5 \mathrm{~m}-10 \mathrm{~m}$ from 200 quadrats, all over the 2 years combined. Percentages are the total number of quadrats in which each species was present in proportion to the total number of quadrats within the treatment group. Chisquare tests for differences in frequency of species/growth forms between the three zones over expected values. A \# represents species endemic to the Kosciuszko alpine zone, a $\mathbf{\$}$ symbolises species listed as vulnerable under federal law and $a *$ indicates a weed species.

\begin{tabular}{|c|c|c|c|c|c|c|c|}
\hline Species Name & Trail Centre & $\%$ & Edges & $\%$ & $5 m-10 m$ & $\%$ & Chi-square \\
\hline Oreomyrrhis eriopoda & & & 5 & 5 & 3 & 1.5 & \\
\hline Aciphylla glacialis & & & & & 1 & 0.5 & \\
\hline Brachyscome spathulata ssp. spathulata & & & 4 & 4 & 3 & 1.5 & \\
\hline Celmisia costiniana & & & 1 & 1 & 5 & 2.5 & \\
\hline Craspedia jamesii & & & & & 1 & 0.5 & \\
\hline Ewartia nubigena & 14 & 7 & 36 & 36 & 26 & 13 & $p<0.001$ \\
\hline Leptorhynchos squamatus & 1 & 0.5 & 2 & 2 & 6 & 6 & \\
\hline Leucochrysum albicans ssp. alpinum & & & 8 & 8 & 14 & 7 & \\
\hline Senecio pectinatus var. major & 6 & 3 & 42 & 42 & 76 & 38 & $\mathrm{p}<0.001$ \\
\hline Colobanthus pulvinatus & 40 & 80 & 97 & 97 & 181 & 90.5 & $p=0.435$ \\
\hline Scleranthus singuliflorus & & & 6 & 6 & 11 & 5.5 & \\
\hline Epacris gunnii & & & 73 & 73 & 184 & 92 & \\
\hline Epacris petrophila & 2 & 4 & 8 & 8 & 16 & 8 & $p=0.007$ \\
\hline Luzula australasica ssp. dura \# & 46 & 92 & 100 & 100 & 190 & 95 & $p=0.843$ \\
\hline Agrostis muelleriana & 19 & 38 & 46 & 46 & 82 & 41 & $p=0.676$ \\
\hline Poa fawcettiae & 24 & 48 & 43 & 43 & 63 & 31.5 & $p=0.195$ \\
\hline Rytidosperma nudiflorum & & & 2 & 2 & 5 & 2.5 & \\
\hline Rytidosperma pumilum $\$$ & 20 & 40 & 84 & 84 & 151 & 75.5 & $p<0.001$ \\
\hline Trisetum spicatum ssp. australiense & 40 & 80 & 90 & 90 & 179 & 89.5 & $p=0.681$ \\
\hline Acetosella vulgaris * & 7 & 14 & 20 & 20 & 49 & 24.5 & $p=0.214$ \\
\hline Ranunculus acrophilus \# & 26 & 52 & 93 & 93 & 170 & 85 & $p=0.002$ \\
\hline Euphrasia collina ssp. lapidosa \# & 3 & 6 & 86 & 86 & 188 & 94 & $p<0.001$ \\
\hline Veronica densifolia & & & 5 & 5 & 41 & 20.5 & \\
\hline Plantago muelleri & & & 1 & 1 & & & \\
\hline Epilobium tasmanicum & & & 3 & 3 & 5 & 2.5 & \\
\hline Kelleria dieffenbachii & 4 & 8 & 35 & 35 & 51 & 25.5 & $\mathrm{p}=<0.001$ \\
\hline Lycopodium fastigiatum & 1 & 2 & 3 & 3 & 4 & 2 & \\
\hline Shrubs & & 4 & & 38.7 & & 41.8 & $p=<0.001$ \\
\hline Herbs & & 5.7 & & 18.3 & & 19.1 & $p=0.026$ \\
\hline Graminoids & & 54 & & 66.5 & & 51.8 & $p=0.317$ \\
\hline Cushions & & 49.7 & & 60.8 & & 55.8 & $p=0.580$ \\
\hline
\end{tabular}




\section{Discussion}

Sclerophyllous shrub-dominated communities, including in alpine areas appear to be very sensitive to human trampling (Bayfield 1979; McDougall and Wright 2004; Kim and Daigle 2011). In this study we found a clear effect of a hiking trail on the composition of a rare plant community when conditions had been very dry and differences remained even when conditions were wetter.

\subsection{Effects of the trail on Windswept Feldmark}

The hiking trail affected the composition of Windswept Feldmark in both surveys. The surface of the trail consisted mainly of bare ground in both surveys with a scattering of graminoids and cushion plants that appear to be less sensitive to trampling than herbs and shrubs in this community. Increasing bare ground is a common and rapidly-occurring effect of trampling along popular routes, with both the exposure of mineral soil and direct trampling damage making these types of heavily disturbed environment unsuitable for many plant species (Liddle, 1997; Leung and Marion, 2000; Pickering and Hill, 2007). Graminoids have often been found to be among the species most tolerant of trampling, often more so than herbs and shrubs (Liddle 1997; Hill and Pickering 2009). Graminoids often have basal meristems, papery sheaths and flexible cells which can contribute to their tolerance of trampling and many have plastic responses to counter the impacts of crushing (Liddle 1997). As a result grasses often dominate trail floras (Sun and Liddle 1993; Hemp 2008).

Although cushion plants such as Colobanthus pulvinatus were largely tolerant of trampling in this study, a range of responses have been found for cushion plants in other studies of trampling. Some found that cushion plants had limited tolerance for trampling (Willard and Marr 1970; Willard and Marr 1971; Gremmen et al. 2003), while others found that on moderate trail-use, cushions could persist due to their compact growth-form and the selective removal of competitive shrubs (Whinam and Chilcott 2003).

Several of the herbs in the Windswept Feldmark were sensitive to trampling. Those that tended to be more tolerant often had more resistant structures such as rosette growth-forms such as Ranunculus acrophilus and hence may have been better able to deal with conditions on the trail than thin-celled, erect herbs such as Scleranthus singuliflorus. Rosette plants often have flexible, flattened leaves that grow parallel to foot-fall and hemicryptophytic central perennating buds that are not easily crushed from above (Liddle 1991; Bernhardt-Römermann et al. 2011).

The dominant shrub in the Windswept feldmark Epacris gunnii with its small leaves, short internodes and prostrate sprawling form (Pickering and Venn 2013) appears unable to tolerate trampling in dry conditions (McDougall and Wright 2004). Despite an increase in the cover of this species between surveys, it was just as sensitive to trampling in 2013 as 2003, with the cover of the shrub still much lower on the trail edge than further away and no shrubs found on the trail surface itself. These results are consistent with other studies that have found that shrubs with above-ground perennating stems and slower growth rates are often unable to tolerate even low levels of trampling (Dale and Weaver 1974; Cole and Spildie 1998; Atik et al. 2009).

The trail edges in the Windswept Feldmark were affected by trampling, but to a lesser extent than the trail surface resulting in four times the diversity on the trail edge than on the trail surface. Intermittent disturbance on trail edges sometimes increases plant diversity compared to further 
from the trail by favouring some trampling tolerant species, but not at the expense of all of the trampling sensitive species (Sun and Liddle 1993; Kutiel et al. 1999; Grunewald 2006; Lucas-Borja et al. 2011). In the Windswept Feldmark a few species such as Ewartia nubigena and Senecio pectinatus var. major may have benefitted from disturbance along the trail edge, and possibly from the associated reductions in the cover of the dominant shrub. Others herbs such as Scleranthus singuliflorus and Leucochrysum albicans ssp. alpinum may not have benefited from trampling, but appeared to be unaffected by it.

The reduction in Epacris gunnii particularly on the leeward edge of the track in both surveys again supports the suggestion, that the trail may be disrupting its cyclical succession from windward to leeward sides of the ridge (McDougall and Wright 2004). It is possible that the establishment of species such as the herb Euphrasia collina ssp. lapidosa may be facilitated by Epacris gunnii and that the impact of the trail on Epacris gunnii may explain this and some other species' low frequencies, particularly on the lee of the trail. Further research could clarify whether Epacris gunnii does function as a facilitator or 'nurse plant' for other feldmark species and whether, despite the increase in Epacris gunnii cover between surveys, there was still leeward differences in individual shrub number, size, density and recruitment as a result of the trail.

\subsection{Differences between 2003 and 2013}

Despite the localised continuing damage caused by the hiking trail, the general composition of Windswept Feldmark changed between 2003 and 2013, with increased species richness and abundance of some grasses. Similar changes occurred in other plant communities in Australian Alps over this period. In another more regular survey of the same plant community, close to the current site, species richness increased over time, with most of the increase occurring between 2003 and 2006, with richness still much greater in 2012 than 2003 (Pickering and Venn 2013). Sampling of the most common plant community in this alpine area between 2004 and 2011, Tall Alpine Herbfield, close to the current site, also found increases in species richness and in the abundance of graminoids and shrubs (Venn et al. 2012). This included a $22.4 \%$ relative increase in total graminoid cover and a $15 \%$ increase in Epacris cover.

It is likely that at least some of the changes in these alpine plant communities reflect the effects of the warm and dry conditions with limited snowfall characteristic of El Niño conditions and the wetter conditions found during La Niña periods in south-eastern Australia (Australian Government 2013) as well as longer term increases in temperatures and reduced snow cover seen in the region (Pickering and Venn 2013). Some of the changes seen in composition may therefore cycle as conditions alter between wet and dry periods. The years prior to sampling in 2003 included the most severe drought on record in south-eastern Australia with the thirteen years from 1996 to 2009 the driest on record (Wahren et al. 2013) and one of the strongest El Niño events recorded in Australia (Australian Government 2013). In contrast the few years prior to the 2013 sampling was part of a strong La Niña event, were wetter, but remained warm with annual precipitation $491 \mathrm{~mm}$ (42\%) greater between 2008 and 2012 than between 2001 and 2005 (Australian Government 2013). It is possible that with wetter conditions, more competitive species were able to colonise the Windswept Feldmark from the surrounding Tall Alpine Herbfield community including grasses such as Agrostis species (Pickering and Green 2009; Pickering and Venn 2013; Venn et al. 2014). 
The changes found in composition may also reflect the effects of longer term trends in the region; a result of higher temperatures, reduced snow cover and lower precipitation through climate change. Temperatures are predicted to increase by $1^{\circ} \mathrm{C}$ and precipitation to decline by $8.3 \%$ by 2020 compared to 1990 values (Hennessy et al. 2008). The area with more than two months of snow cover per year is also predicted to decline by $60 \%$ (Hennessy et al. 2008). Overall snow cover in the region has already declined by 30\% since the 1950s (Green and Pickering 2009; Green 2010), with a $40 \%$ reduction in snow cover in spring (Nicholls 2005). If climatic conditions continue to be warmer in this region, it is possible that the composition of Windswept Feldmark may become more homogenised with the neighbouring grass-dominated community (Edmonds et al. 2006; Pickering and Venn 2013), and may also be affected by fire, as occurred in some areas of Windswept Feldmark in 2003 (Worboys 2003; Williams et al. 2008; Pickering and Venn 2013).

Increasing species richness and abundance of graminoids and shrubs with increasing temperatures has occurred in other alpine regions around the world. Species richness of summit vegetation in Europe's mountain regions has increased due to the upward range-expansion of lower-altitude plant species (Pauli et al. 2003; Pauli et al. 2012) while some mountain endemics have been lost (Pauli et al. 2012). These long-term, progressive changes are thought to be due, at least in part, to warmer conditions at higher altitudes (Chen et al. 2011; Pauli et al. 2012). Additionally, experimental studies have shown that warming of high altitude/latitude plant communities can have net benefits on shrub and graminoid growth (Hartley et al. 1999; Jägerbrand et al. 2009) thus promoting their increased dominance.

Due to the inability to resample the same quadrats in 2013, it is possible that some of the changes in the Windswept Feldmark were due to sampling errors. However, by sampling the same location, the strict adherence to the same sampling methodology and the use of some of the same members of the survey teams, along with the large number of replicates, we have been able to reduce the impact of any sampling errors and hence large changes in composition are likely to reflect the actual changes in the plant community between surveys.

\subsection{Management implications}

Despite the hiking trail through the Windswept Feldmark receiving relatively low use compared to other trails in the region, it continues to affect this rare and high conservation value plant community. To reduce these impacts, the trail should be realigned where possible to avoid areas of Windswept Feldmark, and where topographic and other factors restrict that option, the use of a raised metal walkway should be considered, as has been already been trialled in one section of Windswept Feldmark (Hill and Pickering 2006). Educational programs such as those used in other popular mountain destinations (Kim and Daigle 2011, 2012) should be implemented to encourage visitors to stay on the current track and avoid further damage to the Windswept Feldmark. Restoration of some areas already damaged could be undertaken, although this is both expensive and can take decades (Scherrer and Pickering 2006).

More long-term monitoring of alpine plant communities to assess the impacts of climate change is already seen as a priority for park agencies in the region (Morrison and Pickering 2012a; Pickering and Venn 2013). Changes in the distribution of some plant communities due to reductions in snow cover have already been documented in the region (Williams et al. 2006; Pickering and Hill 2007; Pickering et al. 2008; Green and Pickering 2009). What is clear from this and other research, is that 
park agencies in many regions of the world, will need to reduce the impacts of a wide range of ecosystem threats, including tourism and recreation, in order to increase the resilience of vegetation to climate change (Morrison and Pickering 2012a; Morrison and Pickering 2012b; Pickering and Venn 2013).

\section{Conclusions}

Changes in the composition of rare Windswept Feldmark have occurred, reflecting both large-scale, long term climatic factors such as cycles of wet and dry periods as well as more localised disturbance by a hiking trail. As the Australian alpine environment is warming and snow cover declining, the abundance of competitive species may increase within Windswept Feldmark. Trampling along the hiking trail continues to affect the community including increases in trampling-tolerant graminoids and cushion plants on the trail but reductions in the abundance of less tolerant herbs and shrubs. The effect of trampling on the dominant shrubs extends to the trail edge where it seems it may even affect its function as a facilitator. Longer-term monitoring would provide additional information about the function and conservation of this plant community and how it is likely to respond to these and other threats.

\section{Acknowledgements}

One of the authors (Ballantyne) would like to acknowledge financial support from the Griffith University Postgraduate Research Scholarship Scheme. Additional funding for the research was also provided by Griffith University. We thank Jon Shuker of Griffith University for his assistance in obtaining and amending GIS information about the Windswept Feldmark and to Dr Clare Morrison for reviewing earlier drafts of the manuscript. We also thank the New South Wales National Parks and Wildlife Service for access to the study site.

\section{References}

Atik M, Sayan S, Karagüzel O (2009) Impact of recreational trampling on the natural vegetation in Termessos National Park, Antalya, Turkey. Tarim Bilimleri Dergisi 15, 249-258.

Australian Government (2013) 'Climate data online.' (Bureau of Meteorology) Available at http://www.bom.gov.au/climate/data/?ref=ftr [Verified 15 May 2014].

Barrow MD (1968) Cyclical changes in an Australian feldmark community. Journal of Ecology 56, 8996.

Bayfield NG (1979) Recovery of four montane heath communities on Cairngorm, Scotland from disturbance by trampling. Biological Conservation 15, 165-178.

Bernhardt-Römermann M, Gray A, Vanbergen AJ, Bergés L, Bohner A, Brooker RW, De Bruyn L, De Cinti B, Dirnböck T, Grandin U, Hester AJ, Kanka R, Klotz S, Loucougaray G, Lundin L, Matteucci G, Mészáros I, Oláh V, Preda E, Prévosto B, Pykälä J, Schmidt W, Taylor ME, Vadineanu A, Waldmann T, Stadler J (2011) Functional traits and local environment predict vegetation responses to disturbance: a pan-European multi-site experiment. Journal of Ecology 99, 777-787. 
Bishop CL, Wardell-Johnson GW, Williams MR (2010) Community-level changes in Banksia woodland following plant pathogen invasion in the Southwest Australian Floristic Region. Journal of Vegetation Science 21, 888-898.

Buckley R (2009) ‘Ecotourism: principles and practises.' (CABI Publishing: Wallingford).

Burns BR, Ward J, Downs TM (2013) Trampling impacts on thermotolerant vegetation of geothermal areas in New Zealand. Environmental Management 52, 1463-1473.

Callaway RM (1995) Positive interactions among plants. Botanical Review 61, 306-349.

Chen IC, Hill JK, Ohlemüller R, Roy DB, Thomas CD (2011) Rapid range shifts of species associated with high levels of climate warming. Science 333, 1024-1026.

Clarke KR (1993) Non-parametric multivariate analyses of change in community structure. Australian Journal of Ecology 18, 117-143.

Cole DN, Spildie DR (1998) Hiker, horse and llama trampling effects on native vegetation in Montana, USA. Journal of Environmental Management 53, 61-71.

Cole DN (2004) Impacts of hiking and camping on soils and vegetation: a review. In 'Environmental Impacts of Ecotourism.' (Ed R Buckley) pp. 41-61. (CABI Publishing: Wallingford).

Costin A, Gray M, Totterdell C, Wimbush D (1979) 'Kosciuszko alpine flora.' First edition. (CSIRO Publishing, Canberra).

Costin AB, Gray M, Totterdell C, Wimbush D (2000) 'Kosciuszko alpine flora.' Second edition. (CSIRO Publishing, Canberra).

Dale D, Weaver T (1974) Trampling effects on vegetation of the trail corridors of North Rocky Mountain forests. Journal of Applied Ecology 11, 767-772.

Edmonds T, Lunt ID, Roshier DA, Louis J (2006) Annual variation in the distribution of summer snowdrifts in the Kosciuszko alpine area, Australia, and its effect on the composition and structure of alpine vegetation. Austral Ecology 31, 837-848.

Edwards IJ (1977) The ecological impact of pedestrian traffic on alpine vegetation in Kosciuszko National Park. Australian Forestry 40, 108-120.

Farrell TA, Marion JL (2001) Identifying and assessing ecotourism visitor impacts at eight protected areas in Costa Rica and Belize. Environmental Conservation 28, 215-225.

Farrell TA, Marion JL (2002) Trail impacts and trail impact management related to ecotourism visitation at Torres del Paine National Park, Chile. Journal of the Canadian Association for Leisure Studies 26, 31-59.

Green K (2010) Alpine taxa exhibit differing responses to climate warming in the Snowy Mountains of Australia. Journal of Mountain Science 7, 167-175. 
Green K, Pickering CM (2009) The decline of snowpatches in the Snowy Mountains of Australia: importance of climate warming, variable snow and wind. Arctic, Antarctic and Alpine Research 41, 212-218.

Greenwood PE, Nikulin S (1996) 'A guide to Chi-squared testing'. (Wiley and Sons Publishing, New York).

Gremmen NJM, Smith VR, Van Tongeren OFR (2003) Impact of trampling on the vegetation of subantarctic Marion Island. Arctic, Antarctic and Alpine Research 35, 442-446.

Growcock AJW (2006) Impacts of camping and trampling on Australian alpine and subalpine vegetation and soils. PhD Thesis, Griffith University, Australia. 114 p.

Grunewald R (2006) Assessment of damages from recreational activities on coastal dunes of the Southern Baltic Sea. Journal of Coastal Research 22, 1145-1157.

Hartley AE, Neill C, Melillo JM, Crabtree R, Bowles FP (1999) Plant performance and soil nitrogen mineralisation in response to simulated climate change in subarctic dwarf shrub heath. OIKOS 86, 331-343.

Hemp A (2008) Introduced plants on Kilimanjaro: tourism and its impact. Plant Ecology 197, 17-29.

Hennessy KJ, Whetton PH, Walsh K (2008) Climate change effects on snow conditions in mainland Australia and adaptation at ski resorts through snow making. Climate Research 35, 255-270.

Hill W, Pickering CM (2006) Vegetation associated with different walking track types in the Kosciuszko alpine area, Australia. Journal of Environmental Management 78, 24-34.

Hill W, Pickering CM (2009) Differences in resistance of three sub-tropical vegetation types to experimental trampling. Journal of Environmental Management 90, 1305-1312.

Jägerbrand AK, Alatalo JM, Chrimes D, Molau U (2009) Plant community responses to 5 years of simulated climate change in meadow and heath ecosystems at a subarctic-alpine site. Oecologia 161, 601-610.

Kerbiriou C, Leviol I, Jiguet F, Julliard R (2008) The impact of human frequentation on coastal vegetation in a biosphere reserve. Journal of Environmental Management 88, 715-728.

Kim MK, Daigle JJ (2011) Detecting vegetation cover change on the summit of Cadillac Mountain using multi-temporal remote sensing datasets: 1979, 2001 and 2007. Environmental Monitoring and Assessment 180, 63-75.

Kim MK, Daigle JJ (2012) Monitoring of vegetation impact due to trampling on Cadillac Mountain summit using high spatial resolution remote sensing data sets. Environmental Management 50, 956968.

Kissling M, Hegetschweiler KT, Rusterholz HP, Baur B (2009) Short-term and long-term effects of human trampling on above-ground vegetation, soil density, soil organic matter and soil microbial processes in suburban beech forests. Applied Soil Ecology 42, 303-314. 
Kutiel P, Zhevelev H, Harrison R (1999) The effect of recreational impacts on soil and vegetation of stabilised Coastal Dunes in the Sharon Park, Israel. Ocean and Coastal Management 42, 1041-1060.

Lambert D (1992) Zero-inflated Poisson regression, with an application to defects in manufacturing. Technometrics 34, 1-14.

Leung YF, Marion JL (1999) Assessing trail conditions in protected areas: application of a problemassessment method in Great Smoky Mountains National Park, USA. Environmental Conservation 26, 270-279.

Leung YF, Marion JL (2000) Recreation impacts and management in wilderness: A state-ofknowledge review. USDA Forest Service Proceedings 15, 23-48.

Liddle MJ (1975) A selective review of the ecological effects of human trampling on natural ecosystems. Biological Conservation 7, 17-33.

Liddle MJ (1991) Recreation ecology: effects of trampling on plants and corals. TREE 6, 13-17.

Liddle MJ (1997) ‘Recreation Ecology’. (Chapman and Hall Publishing, London).

Lucas-Borja ME, Bastida F, Moreno JL, Nicolás C, Andres M, López FR, Del Cerro A (2011) The effects of human trampling on the microbiological properties of soil and vegetation in Mediterranean mountain areas. Land Degradation and Development 22, 383-394.

Lynch AJJ, Kirkpatrick JB (1995) Pattern and process in alpine vegetation and landforms at Hill One, Southern Range, Tasmania. Australian Journal of Botany 43, 537-554.

Malmivaara-Lämsä M, Hamberg L, Haapamäki E, Liski J, Kotze DJ, Lehvävirta S, Frtize H (2008) Edge effects and trampling in boreal urban forest fragments - impacts on the soil microbial community. Soil Biology and Biochemistry 40, 1612-1621.

Marzano M, Dandy N (2012) Recreationist behaviour in forests and the disturbance to wildlife. Biodiversity and Conservation 21, 2967-2986.

McDougall KL, Wright GT (2004) The impact of trampling on feldmark vegetation in Kosciuszko National Park, New South Wales. Australian Journal of Botany 52, 315-320.

McDougall KL, Walsh NG (2007) Treeless vegetation of the Australian Alps. Cunninghamia 10, 1-57.

Mende P, Newsome D (2006) The assessment, monitoring and management of hiking trails: a case study from the Stirling Range National Park, Western Australia. Conservation Science Western Australia 5, 285-295.

Monz CA, Cole DN, Leung YF, Marion JL (2010) Sustaining visitor use in protected areas: future opportunities in recreation ecology research based on the USA experience. Environmental Management 43, 551-562.

Monz CA, Pickering CM, Hadwen WL (2013) Recent advances in recreation ecology and the implications of different relationships between recreation use and ecological impacts. Frontiers in Ecology and the Environment 11, 1-7. 
Morrison C, Pickering CM (2012a) Limits to climate change adaptation: case study of the Australian Alps. Geographical Research 51, 11-25.

Morrison C, Pickering CM (2012b) Perceptions of the ski tourism industry and others to impacts, adaptation and limits to adaption to climate change in the Australian Alps. Journal of Sustainable Tourism 21, 173-191.

Moro MJ, Pugnaire FI, Haase P, Puigdefábregas J (1997) Mechanisms of interaction between a leguminous shrub and its understorey in a semi-arid environment. Ecography 20, 175-184.

Newsome D, Moore SA, Dowling RK (2013) 'Natural area tourism: ecology, impacts and management.' Second edition. (Channel View Publications, Bristol).

Nicholls N (2005) Climate variability, climate change and the Australian snow season. Australian Meteorological Magazine 54, 177-185.

Olive ND, Marion JL (2009) The influence of use-related, environmental and managerial factors on soil loss from recreational trails. Journal of Environmental Management 90, 1483-1493.

Pauli H, Gottfried M, Grabherr G (2003) The Piz Linard (3,411m), the Grisons, Switzerland - Europe's oldest mountain vegetation study site. Ecological Studies 167, 443-448.

Pauli H, Gottfried M, Dullinger S, Abdaladze O, Akhalkatsi M, Benito Alonso JL, Coldea G, Dick J, Erschbamer B, Fernández Calzado R, Ghosn D, Holten JI, Kanka R, Kazakis G, Kollár J, Larsson P, Moiseev P, Moiseev D, Molau U, Molero Mesa J, Nagy L, Pelino G, Puşcaş M, Rossi G, Stanisci A, Syverhuset AO, Theurillat JP, Tomaselli M, Unterluggauer Villar L, Vittoz P, Grabherr G (2012) Recent plant diversity changes on Europe's mountain summits. Science 336, 353-355.

Phillips N, Newsome D (2002) Understanding the impacts of recreation in Australia protected areas: quantifying damage caused by horse riding in D'Entrecasteaux National Park, Western Australia. Pacific Conservation Biology 7, 256-273.

Pickering CM, Buckley RC (2003) Swarming to the summit: managing tourists at Mt Kosciuszko, Australia. Mountain Research and Development 23, 230-233.

Pickering CM, Johnston S, Green K, Enders G (2003) Impacts of nature tourism on the Mount Kosciuszko alpine area, Australia. In 'Nature-based tourism: environment and land management.' (Eds R Buckley, Pickering CM, Weaver DB). pp. 123-135. (CABI Publishing, Wallingford).

Pickering CM, Hill W (2007) Impacts of recreation and tourism on plant biodiversity and vegetation in protected areas in Australia. Journal of Environmental Management 85, 791-800.

Pickering CM, Hill W, Green K (2008) Vascular plant diversity and climate change in the alpine zone of the Snowy Mountains, Australia. Biodiversity and Conservation 17, 1627-1644.

Pickering CM, Green K (2009) Vascular plant distribution in relation to topography, soils and microclimate at five GLORIA sites in the Snowy Mountains, Australia. Australian Journal of Botany 57, 189199. 
Pickering CM, Growcock AJ (2009) Impacts of experimental trampling on tall alpine herbfields and subalpine grasslands in the Australian Alps. Journal of Environmental Management 91, 532-540.

Pickering CM, Hill W, Newsome D, Leung YF (2010) Comparing hiking, mountain biking and horse riding impacts vegetation and soils in Australia and the United States of America. Journal of Environmental Management 91, 551-562.

Pickering CM, Venn SE (2013) Increasing the resilience of the Australian flora to climate change and associated threats: a plant functional traits approach. (National Climate Change Adaptation Research Facility Publishing, Gold Coast).

PlantNET (2013) 'The New South Wales flora online - a comprehensive botanical treatment in an electronic format.' (PlantNET) Available at http://plantnet.rbgsyd.nsw.gov.au/floraonline.htm [Verified 21 May 2014].

Queiroz RE, Ventura MA, Silva L (2014) Plant diversity in hiking trails crossing Natura 2000 area in the Azores: implications for tourism and nature conservation. Biodiversity and Conservation 23, 13471365.

R Core Development Team (2013) 'The R Project for statistical computing - Version i386 3.0.1.' (The R Project) Available at http://www.r-project.org [Verified 15 May 2014].

Rickard CA, McLachlan A, Kerley GIH (1994) The effects of vehicular and pedestrian traffic on dune vegetation in South Africa. Ocean and Coastal Management 23, 225-247.

Ridout M, Hinde J, Demétrio CGB (2001) A score test for testing zero-inflated Poisson regression model against zero-inflated negative binomial alternatives. Biometrics 57, 219-223.

Scherrer P, Pickering CM (2006) Recovery of alpine herbfield on a closed walking trail in the Kosciuszko alpine zone, Australia. Arctic, Antarctic and Alpine Research 38, 239-248.

Scott JJ, Kirkpatrick JB (1994) Effects of human trampling on the sub-Antarctic vegetation of Macquarie Island. Polar Record 30, 207-220.

Soulé ME, Alberts AC, Bolger DT (1992) The effects of habitat fragmentation on chaparral plants and vertebrates. Oikos 63, 39-47.

Specht RL, Moll EJ (1983) Mediterranean-type heathlands and sclerophyllous shrublands of the world: an overview. Ecological Studies 43, 41-65.

Sun D, Liddle MJ (1993) A survey of trampling effects on vegetation and soil in eight tropical and subtropical sites. Environmental Management 17, 497-510.

Underwood AJ (2002) Analysis of variance. In 'Experiments in ecology.' pp. 140-197. (Cambridge University Press, Cambridge).

Venn S, Pickering CM, Green K (2012) Short-term variation in species richness across an altitudinal gradient of alpine summits. Biodiversity Conservation 21, 3157-3186. 
Wahren CH, Camac JS, Jarrad FC, Williams RJ, Papst WA, Hoffmann AA (2013) Experimental warming and long-term vegetation dynamics in an alpine heathland. Australian Journal of Botany 61, 36-51.

Whinam J, Chilcott NM (2003) Impacts after four years of experimental trampling on alpine/subalpine environments in western Tasmania. Journal of Environmental Management 67, 339-351.

Willard BE, Marr JW (1970) Effects of human activities on alpine tundra ecosystems in Rocky Mountain National Park, Colorado. Biological Conservation 2, 257-265.

Willard BE, Marr JW (1971) Recovery of alpine tundra under protection after damage by human activities in the Rocky Mountains of Colorado. Biological Conservation 3, 181-190.

Williams RJ, Wahren CH, Bradstock RA, Müller WJ (2006) Does alpine grazing reduce blazing? A landscape test of a widely held hypothesis. Austral Ecology 31, 925-936.

Williams RJ, Wahren CH, Tolsma AD, Sanecki GM, Papst WA, Myers BA, McDougall KL, Heinze DA, Green K (2008) Large fires in Australian alpine landscapes: their part in the historical fire regime and their impacts on alpine biodiversity. International Journal of Wildland Fire 17, 793-808.

Wimpey J, Marion JL (2011) A spatial exploration of informal trail networks within Great Falls Park, VA. Journal of Environmental Management 92, 1012-1022.

Worboys GL (2003) A brief report on the 2003 Australian Alps bushfires. Mountain Research and Development 23, 294-295.

Zeileis A, Kleiber C, Jackman S (2008) Regression models for count data in R. Journal of Statistical Software 27, 1-25.

Zuur AF, leno EN, Walker NJ, Saveliev AA, Smith GM (2009) Zero-truncated and zero-inflated models for count data. In 'Mixed effects models and extensions in ecology with R.' pp. 261-294. (Springer Science Publishing, New York). 


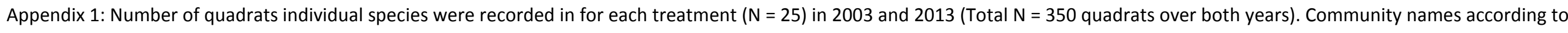

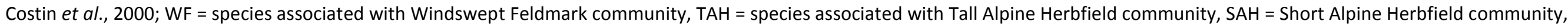

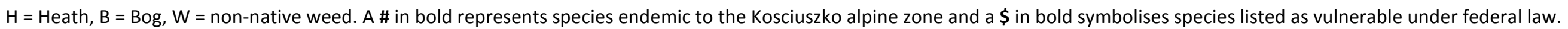

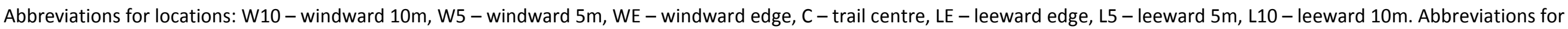
Growth Form (GF): H - herb, C - cushion, S - shrub, G - graminoid, M - clubmoss. GF signifies growth form. Chi-square values for observed vs. expected year effect only.

\begin{tabular}{|c|c|c|c|c|c|c|c|c|c|c|c|c|c|c|c|c|c|c|c|}
\hline \multirow[t]{3}{*}{ GF } & \multirow[t]{3}{*}{ Species Name } & \multirow[t]{3}{*}{ Status } & \multicolumn{14}{|c|}{ Number of quadrats in which the species occurred (/25) } & \multicolumn{2}{|l|}{ Total } & \multirow[t]{2}{*}{ Chi-square } \\
\hline & & & \multicolumn{7}{|c|}{2003} & \multicolumn{7}{|c|}{2013} & \multirow[t]{2}{*}{2003} & \multirow{2}{*}{2013} & \\
\hline & & & W10 & W5 & WE & C & LE & L5 & L10 & W10 & W5 & WE & C & LE & L5 & L10 & & & \\
\hline $\mathrm{H}$ & Oreomyrrhis eriopoda & H/TAH & & & & & 3 & & & 2 & 1 & & & 2 & & & 3 & 5 & \\
\hline $\mathrm{H}$ & Aciphylla glacialis & TAH & & & & & & & & & & & & & 1 & & & 1 & \\
\hline $\mathrm{H}$ & Brachyscome spathulata ssp. & WF/TAH & 1 & 2 & 4 & & & & 3 & & & & & & & & 10 & & \\
\hline $\mathrm{H}$ & Celmisia costiniana & TAH\# & & & & & & & & 2 & 2 & & & 1 & & 1 & & 6 & \\
\hline $\mathrm{H}$ & Craspedia jamesii & TAH/WF & & & & & & & & 1 & & & & & & & & 1 & \\
\hline C & Ewartia nubigena & WF/TAH & 1 & 1 & 6 & 6 & 9 & 2 & 4 & 3 & 2 & 11 & 8 & 10 & 7 & 6 & 29 & 47 & 0.039 \\
\hline $\mathrm{H}$ & Leptorhynchos squamatus & WF/TAH & 1 & & & 1 & & & & 3 & & 1 & & 1 & 1 & 1 & 2 & 7 & \\
\hline $\mathrm{H}$ & Leucochrysum albicans ssp. alpinum & WF/TAH & 1 & 1 & & & 2 & & & 2 & 6 & 3 & & 3 & 2 & 2 & 4 & 18 & 0.003 \\
\hline $\mathrm{H}$ & Senecio pectinatus var. major & WF/TAH & 9 & 8 & 4 & 4 & 14 & 6 & 11 & 8 & 12 & 7 & 2 & 17 & 13 & 9 & 56 & 68 & 0.281 \\
\hline C & Colobanthus pulvinatus & WF/TAH & 24 & 23 & 25 & 19 & 25 & 24 & 25 & 17 & 19 & 23 & 21 & 24 & 24 & 25 & 165 & 153 & 0.501 \\
\hline $\mathrm{H}$ & Scleranthus singuliflorus & WF/TAH & 2 & & & & 2 & & & 2 & 4 & 2 & & 2 & 3 & & 4 & 13 & 0.029 \\
\hline$S$ & Epacris gunnii & $\mathrm{WF} / \mathrm{B} / \mathrm{H}$ & 23 & 24 & 19 & & 12 & 24 & 20 & 22 & 24 & 24 & & 18 & 24 & 23 & 122 & 135 & \\
\hline$S$ & Epacris petrophila & WF & & & & & & & & 3 & 5 & 3 & 2 & 5 & 3 & 5 & & 26 & \\
\hline G & Luzula australasica ssp. dura & WF\# & 23 & 25 & 25 & 23 & 25 & 25 & 25 & 21 & 22 & 25 & 23 & 25 & 24 & 25 & 171 & 165 & 0.743 \\
\hline G & Agrostis muelleriana & WF/TAH & & & & & & & & 20 & 19 & 24 & 19 & 22 & 21 & 22 & & 147 & \\
\hline G & Poa fawcettiae & TAH & 8 & 8 & 5 & 7 & 9 & 3 & 2 & 13 & 11 & 11 & 17 & 18 & 9 & 9 & 42 & 88 & $<0.001$ \\
\hline G & Rytidosperma nudiflorum & $\mathrm{TAH}$ & & & & & & & & 2 & 1 & & & 2 & 2 & & & 7 & \\
\hline G & Rytidosperma pumilum & WF\$ & 13 & 21 & 24 & 5 & 21 & 24 & 23 & 10 & 15 & 20 & 15 & 19 & 23 & 22 & 131 & 124 & 0.661 \\
\hline G & Trisetum spicatum ssp. australiense & TAH & 24 & 25 & 24 & 25 & 24 & 25 & 25 & 22 & 20 & 19 & 15 & 23 & 20 & 18 & 172 & 137 & 0.046 \\
\hline $\mathrm{H}$ & Acetosella vulgaris & w & 11 & 3 & 3 & 3 & 7 & 3 & 4 & 9 & 4 & 6 & 4 & 4 & 6 & 9 & 34 & 42 & 0.359 \\
\hline $\mathrm{H}$ & Ranunculus acrophilus & WF\# & 24 & 19 & 23 & 11 & 22 & 21 & 24 & 22 & 17 & 24 & 15 & 24 & 22 & 21 & 144 & 145 & 0.953 \\
\hline $\mathrm{H}$ & Euphrasia collina ssp. lapidosa & WF\# & 24 & 25 & 25 & 1 & 22 & 25 & 24 & 23 & 21 & 22 & 2 & 17 & 24 & 22 & 146 & 131 & 0.367 \\
\hline $\mathrm{H}$ & Veronica densifolia & WF & 5 & 3 & 1 & & & 3 & 5 & 4 & 5 & 3 & & 1 & 3 & 13 & 17 & 29 & 0.077 \\
\hline $\mathrm{H}$ & Plantago muelleri & SAH & & & & & & & & & & 1 & & & & & & 1 & \\
\hline $\mathrm{H}$ & Epilobium tasmanicum & WF/SAH & & & 1 & & 1 & 2 & 1 & & & & & 1 & 1 & 1 & 5 & 3 & \\
\hline$S$ & Kelleria dieffenbachi & WF & 4 & 6 & 11 & 2 & 9 & 11 & 14 & 3 & 4 & 7 & 2 & 8 & 6 & 3 & 57 & 33 & 0.011 \\
\hline \multirow[t]{2}{*}{ M } & Lycopodium fastigiatum & WF/SAH & & & & & & & 1 & 1 & 1 & 2 & 1 & 1 & & 1 & \multirow[t]{2}{*}{1} & 7 & \\
\hline & & Total & 198 & 194 & 200 & 107 & 207 & 198 & 211 & 215 & 215 & 238 & 146 & 248 & 239 & 238 & & & \\
\hline
\end{tabular}


Appendix 2: Results of post-hoc tests for treatment showing significant differences in main effects between the 7 trail zones: top - Species richness (horizontal) and Number of Ranunculus acrophilus plants (vertical) post-hoc results for treatment (Tukey HSD), bottom - Number of Euphrasia collina ssp. lapidosa plants (horizontal) and Number of sub-quadrats in which Epacris gunnii was present (vertical) post-hoc results for treatment (Tamhane's T2).

\begin{tabular}{llllllll}
\hline & W10 & W5 & WE & C & LE & L5 & L10 \\
\hline W10 & & 1.000 & 0.678 & $<0.001$ & 0.086 & 0.794 & 0.241 \\
W5 & 0.237 & & 0.463 & $<0.001$ & $\mathbf{0 . 0 3 6}$ & 0.593 & 0.119 \\
WE & 0.996 & 0.052 & & $<0.001$ & 0.910 & 1.000 & 0.992 \\
C & $<0.001$ & $\mathbf{0 . 0 0 3}$ & $<0.001$ & & $<0.001$ & $<0.001$ & $<0.001$ \\
LE & 0.984 & $\mathbf{0 . 0 3 1}$ & 1.000 & $<0.001$ & & 0.828 & 0.999 \\
L5 & 0.968 & 0.804 & 0.710 & $<0.001$ & 0.596 & & 0.972 \\
L10 & 0.996 & 0.053 & 1.000 & $<0.001$ & 1.000 & 0.714 & \\
\hline & W10 & W5 & WE & $\mathrm{C}$ & LE & L5 & L10 \\
& & & & & & & \\
\hline W10 & & 1.000 & $\mathbf{0 . 0 4 9}$ & $<0.001$ & $<0.001$ & 1.000 & 1.000 \\
W5 & 0.743 & & 0.261 & $<0.001$ & $<0.001$ & 1.000 & 1.000 \\
WE & 0.096 & $<0.001$ & & $<0.001$ & $\mathbf{0 . 0 4 9}$ & 0.102 & 0.668 \\
C & $\mathrm{n} / \mathrm{a}$ & $\mathrm{n} / \mathrm{a}$ & $\mathrm{n} / \mathrm{a}$ & & $<\mathbf{0 . 0 0 1}$ & $<0.001$ & $<0.001$ \\
LE & $<0.001$ & $<\mathbf{0 . 0 0 1}$ & $<\mathbf{0 . 0 0 1}$ & $\mathrm{n} / \mathrm{a}$ & & $<\mathbf{0 . 0 0 1}$ & $\mathbf{0 . 0 0 2}$ \\
L5 & 1.000 & 0.060 & 0.358 & $\mathrm{n} / \mathrm{a}$ & $<\mathbf{0 . 0 0 1}$ & & 1.000 \\
L10 & 0.516 & $\mathbf{0 . 0 0 2}$ & 1.000 & $\mathrm{n} / \mathrm{a}$ & $<\mathbf{0 . 0 0 1}$ & 0.936 & \\
\hline
\end{tabular}

